\title{
The Current Situation, Problems and Future Paths of Energy Law Education in China
}

\author{
Fu-Guo Cao ${ }^{1}$, Jiang-Yu Huang ${ }^{2}$ \\ ${ }^{1}$ The School of Law, Central University of Finance and Economics, Beijing, P.R. China \\ ${ }^{2}$ The School of Public Finance and Taxation, Central University of Finance and Economics, Beijing, P.R. China
}

Email address:

1136591236@qq.com (Fu-Guo Cao), hjiangyu@email.cufe.edu.cn (Jiang-Yu Huang)

\section{To cite this article:}

Fu-Guo Cao, Jiang-Yu Huang. The Current Situation, Problems and Future Paths of Energy Law Education in China. International Journal of Vocational Education and Training Research. Vol. 4, No. 1, 2018, pp. 13-21. doi: 10.11648/j.ijvetr.20180401.13

Received: March 25, 2018; Accepted: April 27, 2018; Published: May 14, 2018

\begin{abstract}
This article focus on the current situation, problems and suggestions of energy law education in china. We can summarizes some main problems in China's energy law education by comparing the development of energy law education between China and foreign countries in terms of student cultivation, curriculum schedule, university teaching staff, academic research, and public participation. In order to overcome the difficulties in China's energy law education and comply with China's "double first-class" construction and higher education's connotative development requirements, China's energy law education measures include four aspects. First, China must create a "first-class" teaching staff team. Second, China should cultivate innovative, applied, and integrated development energy law students. Third, China should use journals, research centers, and seminars to enhance academic research. Fourth, the Chinese government at all levels, universities, energy industry, energy practitioners, industry associations, and the public should play important roles in achieving co-governance of energy law education.
\end{abstract}

Keywords: Energy Law Education, Current Situation, Future Paths, China

\section{Introduction}

Energy law is a cross discipline of social sciences and natural sciences such as laws, economics, environmental science, ecological science, climate change science and system science. It has comprehensive, technical, multiple values, and soft law, legal norms and other characteristics [1]. As early as the 18th century and the early 19th century, there existed laws governing the energy industry sectors such as coal and petroleum. The oil crisis of the 1970s prompted or led most countries to speed up the formulation of energy policy and laws. It is only at the end of the 20th century that energy law was discussed from the scientific disciplines perspective. Adrian Bradbrook (1996) is the first person to discuss energy law education, who analyzed the changes in curriculum settings and practical development needs of law schools in common law countries. Adrian Bradbrook believed that "Energy law should become an academic discipline," and hoped that all law schools should incorporate "energy Law" into the curriculum. Energy law can be set as a compulsory course or elective course [2]. S. Scott Gaille (2014) analyzed the pressure of the US law school on the training of lawyers and other professional talents. He pointed out that law students should not only learn the theoretical knowledge of energy law, but also master the energy economy, geography science, and engineering etc, to adapt to the characteristics of the interdisciplinary of energy law. Combined with his own experience, this author analyzed the teaching mode and important matters that the part-time teachers of energy law should take in law school [3]. Donna Attanasio (2015) reviewed and introduced the energy law education in the United States in terms of the meaning of the energy law, the goals of the energy law curriculum, the teaching of energy law, and the faculty [4]. Raphael J. Heffron et al. (2016) reviewed the energy law education in the UK before 2016. He believed that energy law education should occupy an important position in the United Kingdom [5].

China's legal education started relatively late. The British and American have a longer period of exploration [6]. There are few academic studies devoted to energy law education in China, and energy law is still in the exploratory stage as a new and interdisciplinary subject. Some scholars have discussed 
the nature of energy law disciplines. Qi Guang and Wang Xiaodong (2006) believed that the philosophy of energy law should reveal the possibility of realizing a better energy life for human society [7]. Wang Canfa and Yu Wenxuan (2008) [8], Cai Shouqiu and Wang Huanhuan (2009)[9] took the energy law as part of the environmental and resource protection law. In this context, they discussed issues such as energy law curriculum and personnel training. Ye Rongsi (2009) [10]and Wu Zhonghu (2009) [11]reviewed the energy legal construction in China in the past 30 years. Sun Yaolin (2010) found out that China's energy law education was weak through literature review, and it still could not provide strong theoretical support for the development of energy law and energy law education [12]. Xiao qiangang (2009, 2012) introduced the development of energy legislation and energy law education in China based on his own academic experience [13]. Huang Zhenzhong (2014) believed that the international energy law should become a new branch of international economic law [14]. Hu Desheng (2017) analyzed the research object, characteristics, research methodology, derived sources, and research objectives of the energy law discipline. He believed that the energy law has become a independent discipline [15].

From the perspective of academic research on energy law education in China and foreign countries, In general, the study of foreign energy law education is in-depth, and its energy law education practice provides detailed data for further research. Britain and the United States provide a comprehensive and systematic summary of the development of the country's energy law discipline respectively in the form of reports. The study of China's energy law education mainly remains in the nature of energy law disciplines, energy law legislation, etc. It lacks analysis of energy law education development issues, domestic and foreign comparisons, and future development paths. This also explains the necessity and significance of the study of China's energy law education.

\section{The Development of Energy Law Education in China}

From 1978 to 1988, China focused on economic development and consumed large amounts of energy. It did not attach importance to energy conservation and caused a serious shortage of energy. During this period, China began to pay attention to energy efficiency, and established an energy conservation strategy. In 1980, experts and scholars in the field of energy wrote the "China Energy Policy Research Report", which included the contents of "Energy and Law".

From 1983 to 1984, a five-person drafting group on "National Energy Legislation" was established. In 1986, China issued the "Regulations on Energy Conservation Management," marking that the energy sector has embarked on the path of legalization. In early 1980, the Ministry of Education approved the "Natural Resources and Energy Law" course in the Department of Law of Peking University. In September 1980, the Ministry of Justice and the Ministry of
Education held the "Economy Law Teaching Material Compilation Conference". China published the first law undergraduate textbook "Economic Law Science." This textbook includes the chapter of "Energy Legal System" [16] In 1985, the "Energy Law" was designated as a professional course in economic law. In 1988, the "Energy Law Tutorial" was published. This is the first college energy law textbook published, marking the initial stage of China's energy law education [17].

According to the legislation on energy, A series of academic researches and energy law textbooks launched by Chinese scholars. In 1996, China published the "Energy Law"in the "Ninth Five-Year Plan" textbook for higher school law. The Chinese Energy Law continues to develop at this stage, and it has been widely recognized by the public. From this stage of 2000-2010, there has been great progress in energy law education, and the pace of energy law and academic research in China has accelerated. The "Research on Major Issues in the Legislation of the Energy Law" was completed in 2007, which has laid important theoretical and methodological foundations for the legislative work of China's Energy Law. More textbooks on the energy law are being published, and talents in energy law education and faculty have been further expanded, Such as Peking University, Tsinghua University, China University of Political Science and Law, Renmin University of China, Beijing Institute of Technology, Zhengzhou University, etc.

At the stage of 2011-2017, the research level of China's energy law has been continuously improved. Many energy law textbooks have been published, and the knowledge system of energy law has been initially established. Energy law scholars created, translated, compiled, and published monographs on the subject of energy law, foreign energy law, comparative energy law, and international energy law. The China Law Society has funded a number of basic research topics in the field of energy law. The energy law teaching and research have been formed nationwide. The group of energy law scientists is expanding, and domestic and international academic (exchange) activities have greatly increased.

\section{Problems of China's Energy Law Education from a Comparative Perspective}

The authors uses "energy law" and "energy law course" as key words to search out the energy law education of nearly 20 colleges and universities in the United States and the United kingdom as sample. There are 13 universities from the United States, which includes: University of Texas, Louisiana State University, West Virginia University, University of California, Berkeley, University of Connecticut; George Washington University, Florida State University, University of Maryland, University of Oklahoma, Vermont Law School, University of San Diego, University of Tulsa, University of Utah; There are 7 colleges and universities from the United kingdom, which includes: University of Dundee, University of Aberdeen, 
University of Queens, London; University of London, Coventry University, Robert Gordon University, University of Reading. The authors search the official websites of these universities and the websites of the American Association of Energy Law Research (EBA), and selects a total of 70 universities and colleges (including research institutes)in China. The energy law academic research mainly includes the publication of selected textbooks and works, academic papers published in core journals. The textbooks, monographs, $\mathrm{Ph} . \mathrm{D}$ thesis on energy law are searched through different libraries in China, the search spans last from 1990 to 2017.

This paper compares China with other countries (the USA and the UK) in terms of teaching staff, personnel training, curriculum, academic research, and public participation, and then analyze the main issues of China's energy law education.

\subsection{The Overall Level of Energy Law Faculty in China Needs to Be Improved}

The energy law faculty in universities in the United Kingdom and the United States has developed rapidly, and more and more scholars have recognized themselves as experts in the field of energy law. Firstly, part-time teachers play an important role in the energy law instructors in universities in the United Kingdom and the United States. For example, some outstanding lawyers from the world's leading energy law firm's had held a series of lectures at Queen Mary University in London, England, to support the school's energy law teaching [18]. The San Diego School of Law in the United States has established a core academic project with a full-time and part-time faculty team. They have brought high-level theoretical research and practical experience for energy law teaching activities [19]. Secondly, the instructors are multidisciplinary and have experience in energy law practice. The special nature of energy law determines that many teachers have an interdisciplinary background. For example, before Anita Schiller joined Dundee University's Energy, Petroleum, and Minerals Law and Policy Center (CEPMLP) in 2013, she worked at the Wind Science and Engineering Research Center at the Lancaster University's Department of Economics and Texas Tech University [20]. Norah, academic director of the School of New Energy and Natural Resources Law at Queen Mary University in London, England, is also a lawyer specializing in international dispute resolution, especially energy investment disputes [21]. These experiences helped them to engage in energy law teaching. Thirdly, the energy scholars' academic research is in-depth and has an international frontier vision. Research on energy law is crucial for energy law education, There are some teachers in the universities of British and American who specialize in academic research. For example, Ms. Nora Gallagher, Dr. Rafael Hefferron and Dr. Rafael Real Arkas have conducted in-depth research on energy law, they published many related works and papers. These teachers not only have theoretical knowledge but also have practical experience. Fourthly, the composition of the faculty of the Energy Law is relatively reasonable. Its research team includes academic leaders, full-time teachers, part-time teachers, and young teachers. The level of energy law faculty directly affects the level and quality of energy law education. According to our statistics on energy law faculty in nearly 70 colleges and research institutes in China, there are nearly 100 faculty members (including professors, associate professors, part-time teachers, lecturers, and researchers) in energy law teaching and full-time research in China. The number of professors (full-time) are approximately 50, accounting for approximately 49\%; the number of associate professors (full-time) are approximately 30 , accounting for approximately $30 \%$; the number of lecturers (full-time) are approximately 10, accounting for approximately $9 \%$; the number of part-time teachers accounting for $6 \%$; there are about 5 researchers, accounting for about $5 \%$. On the whole, China's energy law faculty is gradually growing. However, compared to the China's energy strategy and energy law requirements, the total number and type of teachers in China's energy law education are relatively small. Few Chinese energy law teachers can combine energy law theory teaching with practical experience. There is no hierarchical energy teacher team formed between energy law academic leaders and other teachers. The young teachers in the Energy Faculty team need further improvement.

\subsection{Talents Training at Different Levels in China's Energy Law Is Inadequate}

The cultivation of students in energy law is the basic requirement of the energy revolution. British and American universities attach great importance to training students at different levels in energy law. some schools will train undergraduates in the direction of energy law and award a bachelor's degree in energy law. For example, the University of Dundee in the United Kingdom introduced a degree in energy law at the undergraduate level and a bachelor's degree in oil and gas law [22]. The United States does not have a law undergraduate education, but the school will cultivate interest of the undergraduate in energy law disciplines [23]. Colleges and universities in the United Kingdom and the United States attach great importance to the education of masters in energy law. Their flexible and professional teaching methods not only cultivate their own professional students but also absorb students from all over the world. The master's program of energy law in the University of Dundee includes: energy law and policy, mining law and policy, natural resources law and policy, oil and gas laws and policies, petroleum tax and finance [24]. The master's degrees of School of Law in the University of Texas in the United States include global energy, international arbitration, and environmental law [25]. Cultivating high-level research talents is the key to the sustainable development of energy law disciplines. Britain and the United States attach importance to the cultivation of doctoral candidates for energy law. The American Vermont Law School trains doctoral students in the direction of energy law. Dundee University accepts doctoral students in all fields related to energy law and currently has a number of $\mathrm{PhD}$ candidates engaged in energy reform and governance research [26]. 
Energy law education and students cultivation in Chinese colleges and universities have not yet been able to achieve effective and positive interaction [27]. Compared with the training of students in the USA and the UK Energy Law, China has a significant gap in the training of energy law professionals. Firstly, there are fewer colleges and universities that cultivate energy law professionals. According to the sample statistics, there are fewer colleges specialized in the masters of cultivating energy law(practical types). Only Peking University host a master program in energy law (nuclear policy and law). The proportion of institutions with a master's degree (academic direction) in the direction of energy law is relatively small. Secondly, the degree of internationalization of energy professionals training is not high. The training scope of China's energy law professionals is mainly limited to domestic energy law learning. Thirdly, the quality and efficiency of professional personnel training need to be improved. Chinese universities have fewer types of energy law courses and they are not closely integrated with practice. This makes it more difficult to attract students in energy. In addition, there are not many universities in China that specialize in training doctoral candidates in energy law.

\subsection{Difficulties in the Type and Quantity of Energy Law Curriculum}

The number of energy law courses offered by universities in Britain and the United States continues to increase [28]. The common characteristics of these colleges and universities on energy law courses are: detail-oriented, diversity of species, internationalization, strong practicality. Taking the University of San Diego for example: it has been organizing students to participate in energy law clinic activities every year since 2008, These activities include: organizing students to participate in research projects at the California Public Utilities Commission; collaborating with the California Air Resources Board's Chief Legal Adviser; providing research support for the California Energy Commission; participating in the California Energy Commission's home appliance standards-related research; Conducting cost-effective research in energy company; studying regulations concerning the United States Environmental Protection Agency's Clean Energy Program [29]. The energy law practicing course in the University of Dundee will offer course credits to the energy law students by completing prescribed internship assignments [30]. Holding inter-school competitions in energy law is an important practice. For example, the moot court competition organized by West Virginia University in the US plays a significant role in the study of energy law [31].

Fewer universities in China provide energy law courses, Even if some universities offer energy law courses, their types of courses are unitary, and they are generally named "Energy Law" or "Energy Law Research". These courses cannot meet the requirements of legal education. There is a gap between the economic development and the practical teaching of energy law in China. The practical teaching of the energy law in college plays a key role in the cultivation of energy law talents. China has carried out relevant explorations in the practical teaching of energy law. For example, starting from 2016, the China Energy Law Research Institute will launch the "Green Energy" Cup. All college law students in china can form teams to participate in this competition. This is a large-scale influence of China's energy law education and a combination of energy law theory and practice. However, Chinese universities do less practical teaching of energy law. This also makes it difficult for Chinese graduates of energy law to meet the needs of social employers.

\subsection{Academic Research on Energy Law Can Hardly Support the Sustainable Development of China's Energy Law Education}

The academic study on energy law in the USA and the UK, closely follows the requirements of a new round of energy revolutions and maintains the forefront of academic research on energy law. There are many well-known scholars and academic research results. The Energy Law Research Center has played a prominent role in education. Dundee University Center for Energy, Petroleum and Mineral Law and Policy has a long history and has a relatively large worldwide impact on academic research in energy law [32]. This energy law research center has cultivated and attracted a large number of outstanding scholars. On this platform, energy law scholars discuss leading issues together, publish academic papers with global influence, and promote the development of energy law education in the UK and even have global impact. The University of San Diego's Energy Law Research Center in the United States is responsible for studying energy policy issues affecting the San Diego region and California. They combine academic research with practical policy analysis, law school learning, and public education [33]. The Energy Law Seminar is an important way of energy law education. Universities in the United Kingdom and the United States continue to organize energy law seminars. For example, the University of Dundee in the United Kingdom has set up nine seminars in the first half of 2017, which are all academic issues at the forefront of energy law [34]. Every year, the University of San Diego holds a seminar on climate and energy law. Lawyers, policy-makers, and researchers from laws and policy around the country work together to discuss cutting-edge issues in energy law. Energy law journals play an important role in promoting energy law education. The British energy law professional journals are guided by practical activities or businesses, such as the Journal of Energy and Natural Resources Law of the International Bar Association. The United States places greater emphasis on the establishment of specialized energy law journals through universities [35].

From an academic perspective, China's energy law theory seems to be in a state of popularization. Academic research on energy law has not become the basis for guiding energy policy formulation. The development of academic research on Chinese energy law is lagging behind. The energy law dissertation mainly focuses on the reform and modification of several energy laws. There is a lack of research on theoretical systems of energy law, research on the convergence of interdisciplinary, theoretical research on energy law education, 
and new energy revolution studies on energy law. The energy law academic research teams do not often communicate. There is no stable discipline paradigm in academic research on energy law, and the history of energy law education is not rich enough. China has a certain number of energy law research centers, but their influence on academic research is limited. There are fewer seminars and specialized journals devoted to energy law. The support and protection of energy law academic research are yet to be improved.

\subsection{Public Participation in Energy law Education Is Not Active}

Countries such as the United Kingdom and the United States have more in-depth participation in the field of energy law education. For example, the Energy Bar Association (EBA) focuses on the needs of the industry to discuss how to teach energy law and how to strengthen energy law education. Energy industry companies have made great contributions to improving energy law education, including funding for energy law education; providing special training and guidance for energy law part-time teachers; providing authoritative and professional information for energy law students.

The current shortcomings of China's energy law education are the lack of public governance, which is highlighted by the diversification of higher education and the inadequacy of its ability to coordinate governance [36]. In the energy law education, there is not a sound communication and interaction mechanism between the government, universities, companies, organizations, and other organizations, which has led to the bad connection between the university's energy law education and the needs of social practice.

\section{The Future Paths of China's Energy law Education Under the Connotative Development of Higher Education}

The connotative development of higher education insists on student-oriented; the quality of college teaching, personnel training, etc. The basic evaluation standard is the level of academic research [37]. Through the connotative development, China should give full attention to the fundamental duties of university personnel training, innovation and development, academic research, service to the society, and cultural heritage [38]. The requirement for the development of energy disciplines in the connotative development of higher education is to form a strong academic and creative atmosphere, attract and cultivate outstanding talents, and enable more universities (scientific research institutes) in China to grow into excellent institutions. Based on the analysis of China's first batch of "double first-class" universities [39] "construction plan" found that education policy has an important value guiding role in the construction of the discipline, it is easy to form a reform strategy, to advance, catch up with the practical strategies. Therefore, in the promotion of the "double first-class" policy, the discipline construction of energy law should prevent the narrow construction connotation, excessive management, or disregard the tendency of Chinese characteristics [40]. According to the development of China's energy law education and the requirement of intensified development of higher education, the measures for the improvement of China's energy law education include: building a first-class faculty; cultivating first-class professionals in energy law; and promoting the academic research of energy law; strengthen international cooperation and exchanges; build a community of energy law, to achieve co-governance.

\subsection{Construction of First-Class Faculty of Energy Law}

In energy law education, teachers are strategic and scarce resources for colleges and universities. The core of energy law education is to build a first-class faculty team [41]. The first-class faculty of the energy Law should be a dual-qualified faculty with deep theoretical knowledge and rich practical experience. The quality of teachers directly affects the quality of energy law students and the sustainability of the development of energy law disciplines. The construction of China's energy law faculty should pay attention to the diversity and level of the teacher team. In addition to attaching importance to full-time energy law teachers, universities should introduce energy law practitioners. These teachers have long been engaged in practice and can combine the theory and practice of energy law.

Cultivating academic leaders and academic elites is the key to the construction of a faculty team in China's energy law education. High-level academic team as a strong support is to achieve sustained and healthy development of China's energy law education. This is particularly critical in the context of a new round of highly integrated and complex energy revolutions. According to the characteristics of the cross-discipline of energy law, the innovation team of energy law should ensure that members of different ages and abilities should have diversified knowledge background, thus exerting the best overall effect. At the same time, China should accelerate the training and introduction of a group of energy law leaders and innovation teams, and actively carry out international frontier research work to meet the country's major strategic needs. China should follow the inherent law of teachers' growth and development, and train young and middle-aged teachers who are diligent and academically capable.

\subsection{Cultivate Outstanding Creative Students in Energy Law}

The quality of personnel training is the lifeblood of the university, and the cultivation of first-class talents in energy law requires strong energy law education as a support [42] . In the process of advancing "double first-class" construction and the connotation development of higher education, education plays a leading role in the construction of high-level universities. In promoting first-class education, China must take first-class and innovative students as the fundamental task [43]. Discipline integration can more effectively deal with "important and complex" issues. Therefore, the energy 
law must cultivate students with the innovation, the application, the integrated development.

\subsubsection{Training Energy Law Students at All Levels}

Chinese universities should train energy law talents at all levels, including undergraduates, double bachelors, masters of law, and doctoral students. Through the cultivation of undergraduates, postgraduates, and $\mathrm{PhD}$ candidates in energy law, more professional and high-level talents in energy law will provide for China's economic and social development. The universities should actively cooperates with enterprises and institutions to set up LLM programs in energy law to meet China's requirements for energy law development.

\subsubsection{Setting up Energy Law Courses That Is Conducive to Professional Training}

In order to meet the requirements of the new round of energy revolution, Chinese universities should be able to construct a complete energy law curriculum system which can match the energy industry chains. In accordance with the basic requirements of the energy law curriculum, the teaching scope should be determined scientifically according to the principles of combining theory with practice, reality and foresight, and generality and particularity. The types of courses can be learned from foreign experiences and determined according to the needs of China's energy law practice and research. From a macro perspective, China's energy law curriculum system should at least include energy research, comparative energy law, international energy law, energy law clinics, and energy law academic research. From the microscopic point of view, in accordance with the requirements of the connotative development of higher education and the requirement for double first-class education, china should offer energy law courses with different characteristics, contents and depths for undergraduates of law, double degrees in law, masters of law and $\mathrm{PhD}$ candidates.

\subsubsection{Constructing Textbooks System for Energy Law Professional Training}

In the connotation development of higher education, Textbooks are the most basic teaching resources for the training of excellent students in energy law [44]. After institutional innovation, it fully inspires the participation of stakeholders, such as scientific research workers, universities, and book publishers to promote the compilation, promotion, and use of textbooks [45]. Energy law textbooks are the most basic teaching materials for undergraduates and masters. The quality of textbooks determine the quality of energy law teaching to a certain extent. In order to improve the teaching quality of energy law disciplines, research on energy law teaching materials and methods can be actively carried out, especially the energy law knowledge system, case study courses, and energy law internships. Through exchange of experiences, Chinese universities can improve the quality of energy law teaching.

In order to solve the problems of relatively few textbooks, academic papers and master thesis in the field of energy law, china must firstly pay attention to the construction of energy law textbooks. The construction of China's energy law textbooks will bring together authoritative experts in energy law theory and practice from all over the world. On the basis of summarizing the existing research results, a series of textbooks have organized and published in china. Through the compilation of energy law textbooks, china can promote the formation of energy law knowledge system. Chinese universities should focus on strengthening the research on the basic methods and basic categories of energy law research. And summarize the basic concept system and the principle system, clarify the relationship between energy law and other disciplines. And provide standards for university energy law teaching.

\subsubsection{Promoting International Cooperation in Energy Law Education}

Under the background of the connotative development of higher education and the "double first-class" construction, in order to meet the requirements of the new round of energy revolution, China should actively carry out the dialogue and exchange of international energy policies [46], and strengthen international cooperation and exchange of energy law education. On the one hand, China should attach importance to the employment of foreign energy law experts and support domestic experts, scholars or students to participate in the international energy law exchange conferences. Through the international cooperation and exchange of energy law experience, an international exchange platform for energy law will be set up, and promote the internationalization of energy law education in China. On the other hand, China can cooperate with foreign universities to establish courses in the summer or winter holidays. The cultivation of students in the energy law should encourage and promote"open classes, shared teaching resources, and international collaboration". International cooperation teaching classes can promote energy law to transform education methods. Through broadening the channels of foreign exchanges for the construction of energy law disciplines and conducting exchange visits and exchanges, we will improve the advanced personnel training modes and teaching methods.

\subsection{Raising the Level of Academic Research in Energy Law}

China's academic research on energy law is reflected in the process of serving the society. This requires us to persist in conducting problem-oriented research, raising the level of basic research, strengthening cross-disciplinary integration, and promoting cooperation between industry and universities [47]. In the academic research of China's energy law, it is necessary to reconstruct the energy law discipline system and conduct a comprehensive study according to the Chinese context and problem orientation. China's energy law education should strengthen the academic reflection of energy law theory and promote the vertical and horizontal extension of academic research. Pay attention to professional journals, school newspapers, seminars, etc. to provide a guarantee mechanism for academic research.

China's energy law has gradually been recognized by the 
public. The academic community of energy law research contributes to the construction of an energy law academic system. Under the background of the rule of law and the energy revolution, energy law research should face real social problems, find internal features, refine theories and improve the ability to solve problems. Academic research on energy law is conducive to building a modern Chinese legal research system.

The important support for academic research on energy law include the Energy Law Innovation Research Center, the Energy Law Series Seminar, and the Energy Law Professional Journal. Chinese universities should pay attention to the role of energy law research centers, carry out series of energy law seminars, and support university journals. Professional research institutes and continuous seminars provide a platform for the exchange of energy law academic research. Professional journals provide a means of dissemination for academic achievements in energy law and promote debate in China's energy law academic research.

\subsection{Energy Law Community Promotes Energy Law Education}

The governance of higher education requires the joint efforts of government authorities, universities and the public. Teaching, research, and social services have gradually become clear as the mission of the university, and the requirements for external intervention have become stronger. Under the new round of energy revolution, in accordance with the requirements of the connotative development of higher education and the "double first-class" construction, in order to deal with the predicament of the construction of the discipline of energy law in our country, China should pay attention to the co-governance of higher education. In addition to attaching importance to energy law faculty, personnel training, academic research, etc., it is also necessary to form a fate community for the construction of energy law disciplines (communities include governments, universities, industrial enterprises, employees, industry associations, the public, etc.).

\subsubsection{Government Plays a Role in Organizational Management in Energy Law Education}

The Chinese government should strengthen the organization and management of energy law education, further study the foundation, advantages and development potential of energy law education, and formulate scientific development plans. China encourages and supports different types of universities for differentiated development, and promotes energy law discipline of some universities to become the world-class. The government should give financial support to the university's energy law education, introduce third-party institutions to participate in the evaluation of teaching quality. The government shall improve the financial performance system in education and make timely and dynamic adjustments based on the results of energy law education performance evaluation. The government should adopt various measures to enhance the quality and efficiency of energy law education.

\subsubsection{Improve the Internal Governance of Universities Energy Law Education}

The university is a key platform for energy law education. Chinese universities should "implement the governance structure and institutional system with the school constitution as the core." [48] The modern higher education system in China requires the application of academic energy research results in universities. In accordance with the requirements of economic and social development, university energy law education should become an important contribution to the energy industry's technological change and innovation drive.

\subsubsection{Energy Law Company Plays an Effective Role in the Supervision of Energy Law Education}

The enterprise is the main service target of energy law education and the final destination of energy law graduates. Employment is the "touchstone" of the effectiveness and qualities of university energy law education. University courses, academic research, and graduates must all accept the final test of the market. On the one hand, Chinese universities should improve their professional and practical skills in accordance with the requirements of the employment of enterprises; on the other hand, Chinese universities must cooperate with enterprises and institutions to improve students' communication abilities and problems solving skills. In particular, universities should pay attention to the energy companies' feedback on students and work with companies to find solutions. Therefore, enterprises in the energy law industry must be involved in the quality evaluation of energy law education.

\subsubsection{Energy Industry Association Plays a Key Role in Energy Law Education}

The purpose and mission of the industry association to participate in the education of energy law is to promote education modernization and promote the achievement of social democracy, fairness, efficiency and other goals. The three main functions of industry associations are participation in management, social service, and communication and coordination [49]. Based on the three major functions of industry associations, the activities that can be carried out by the industry associations of China's energy law in the construction of energy law disciplines include four aspects. First, raise funds for energy law education; encourage more legal students to choose energy law professions as occupations; provide scholarships for energy law students; sponsor energy moot court or dissertation competitions; provide funding for energy research centers, institutions, etc.

Second, provide training courses for practitioners interested in engaging in part-time energy law professors. Provide the university with professors with practical experience in energy law.

Third, the Association will build bridges for potential employers of energy law and energy law students. Provide energy recruitment information for energy law higher education schools, share academic research results and energy law education training courses for energy law students. And provide internship opportunities and share corporate 
recruitment information. The association creates interactive opportunities and platforms for universities, students and energy law companies so that all parties can participate in energy law education.

\subsubsection{Public Participation in the Supervision of Energy Law Education}

Energy is closely related to everyone's interests. The public is the most basic and key "cell" of the energy law community. They play supervisory roles in the education of energy law. Public participation in the supervision of energy law education reflects the basic requirements for the modernization of China's educational governance. This requires education departments and higher education schools at all levels to take the initiative to strengthen information disclosure in energy law education and respond to public inquiries, queries, etc., and ensure that the public can obtain all kinds of energy law education information in a timely, comprehensive, accurate, efficient, and convenient manner [50].

\section{Conclusion}

Deep-seated structural and institutional conflicts have become important factors that restricts the sustainable development of energy in China's "13th Five-Year Plan". Energy law education is an important support for the realization of legalization in the field of energy. This article uses literature research methods, comparative research methods. Combing the current status of China's energy law education and the urgent needs of a new round of energy revolution.

Based on the comparison between China and the foreign countries(mainly the USA, the UK), the authors conclude that China's energy law discipline construction faces difficulties and problems. According to the requirements of the connotative development and "double first-class" construction of higher education, China should establish a first-class faculty, cultivate innovative energy law professionals, and form a community of energy law. The development of energy law education in our country is a process of "long way". The energy law community in china should recognize the current situation, grasp the new requirements accurately and future trends of the energy revolution. We can contribute to the development of energy law education for the world.

\section{Acknowledgements}

This paper is based on a research project financially supported by the National Social Science Foundation of China, entitled "Research on Public-Private Partnership Legislation" (Grant number: 15ZDB174) and financially supported by "Central University of Finance and Economics Graduate Research Innovation Fund”.

\section{References}

[1] Hu Desheng. (2017). Energy Law. Peking University Press, 44-46.
[2] Adrian Bradbrook (1996). Energy Law as an Academic Discipline, Energy \& Nat. Resources L, (14):193-217.

[3] S. Scott Gaille, The ABA Task Force Report on the Future of Legal Education: The Role of Adjunct Professors and Practical Teaching in the Energy Sector, Energy L. J. 2014, (35):199-214.

[4] US Energy Bar Association (Donna Attanasio, Committee Chair),. (2015). 'Energy Law Education in the U. S.: An Overview and Recommendations'. Energy Law Journal, (36):217.

[5] Raphael J. Heffron, Peter Roberts, Peter Cameron, Angus Johnston,. (2016). A review of energy law education in the UK, Journal of World Energy Law and Business, (09), 346-356.

[6] Fang Liufang. Questioning the law education [J]. China Legal Science, 2008, (06): 14-21.

[7] Qi Guang, Wang Xiao-dong. (2006) Philosophical Thinking on Law of Energy: Connotation, Principle Attribute and Themes. Academic Exchange, (12): 64-67.

[8] Wang Can-fa and Yu Wen-xuan (2008). On Course Arrangement and Textbook Compiling in Environmental Law Education in China, Contemporary Law Science,(06):144-151.

[9] Cai Shou-qiu and Wang Huan-huan (2009). 30 years of reform and opening up: China's development of environmental resources law, environmental resources law and environmental resources law education development, Journal of Gansu Political Science and Law Institute,(03):1-9.

[10] Ye Rongsi (2009). Review and Prospect: China's Energy Legal System Building Since the Reform and Opening-up, Journal of Zhengzhou University (Philosophy and Social Science Edition),(03): 61-64.

[11] Wu Zhonghu (2009). Experience and Enlightenment: 30 Years of Energy Legal System Construction in China, Journal of Zhengzhou University (Philosophy and Social Science Edition), (03): 65-67.

[12] Sun Yaolin (2010), The trajectory and direction of energy law research in energy law, Journal of Henan Normal University(Philosophy and Social Science),(01):90-92.

[13] Xiao Qiangang (2009). I and Energy Law and Natural Resources Law--Summarize the creation and development of two new disciplines $[\mathrm{J}]$. Proceedings of the First China Law Masters Forum, 648-654.

[14] Huang Zhenzhong (2014). On the Nature and Genus of International Energy Law, Journal of Beijing Normal University (Social Science Edition), (01): 134-139.

[15] Hu Desheng (2017). Energy Law, Peking University Press, 30-31.

[16] Tao Heqian (1983). Economic Law, Mass Press.

[17] Xiao Gangang, Wei Zongqi (1988). Energy Law Tutorial, Law Press.

[18] Queen Mary University of London, retrieved May 10, 2017, from. http://www.qmul.ac.uk/postgraduate/taught/coursefinder/cours es/121362.html.

[19] The San Diego School of Law, Retrieved May 10, 2017, from http://www.sandiego.edu/law/faculty/. 
[20] Dundee University, retrieved October 2, 2017, from https://www.dundee.ac.uk/cepmlp/staff/details/schiller-anita.p hp.

[21] Queen Mary Fellows, retrieved May 10, 2017, from http://www.qmul.ac.uk/research/acclaimed-academics/fellows/ index.html.

[22] Dundee University Graduate Programs at a Glance retrieved October 2, 2017, from http://www.universityofdundee.cn/schools-courses/pg-courses. html.

[23] US Energy Bar Association (Donna Attanasio, Committee Chair),.(2015)'Energy Law Education in the U.S.: An Overview and Recommendations', Energy Law Journal,(36): 218-240.

[24] University of Dundee Course Finder: LLM, retrieved October 2, 2017, from

https://search.dundee.ac.uk/s/search.html?collection=courses \&query=LLM\&frmSubmit=.

[25] Global Energy, International Arbitration and Environmental Law, retrieved January 14, 2018, from

https://law.utexas.edu/master-of-laws/llm-concentrations/glob al-energy-international-arbitration-and-environmental-law/.

[26] PhD Programme at CEPMLP, recognition, retrieved January 14, 2018, from

https://www.dundee.ac.uk/cepmlp/postgraduatestudy/phdprogr amme/.

[27] Ni Yahong, Wang Yunlai(2017). The practice unity of education and talent cultivation under the background of "double-class" strategy, Jiangsu Higher Education, (02): 7-15.

[28] Raphael J. Heffron, Peter Roberts, Peter Cameron, Angus Johnston (2016). A review of energy law education in the UK, Journal of World Energy Law and Business, (9): 346-356.

[29] Energy Law and Policy Clinic, retrieved January 14, 2018, from

http://www.sandiego.edu/law/centers/epic/classes-clinics/clini c.php. Energy Clinic, Environmental and Natural Resources Law Clinic, retrieved January 10, 2018, from http://www.vermontlaw.edu/academics/clinics-and-externship s.

[30] Legal clinics, retrieved January 14, 2018, from https://www.dundee.ac.uk/study/pg/.

[31] West Virginia Moot Court Competitionretrieved January 14, 2018, from http://graduateadmissions.wvu.edu/home.

[32] Dundee University Center for Energy, Petroleum and Mineral Law and Policy, retrieved January 8, 2018, from https://www.dundee.ac.uk/cepmlp.

[33] Energy Policy Initiatives Center, retrieved February 19, 2018, from http://www.sandiego.edu/law/centers/epic/.

[34] Seminars, retrieved February 19, 2018, from https://www.dundee.ac.uk/cepmlp/research/seminars/.

[35] Raphael J. Heffron, Peter Roberts, Peter Cameron, Angus Johnston( 2016). A review of energy law education in the UK, Journal of World Energy Law and Business, (9): 354.
[36] Tang Dongsheng (2015). Promoting modernization of education governance with the reform of higher education as a breakthrough, People's Tribune, (11): 135.

[37] Liu Zhen-tian (2014). From the Extensive Development to the Connotative Development: The value Change of China Higher Education in the Transition Period, Journal of Higher Education, (09): 1-7.

[38] Zhang Dexiang, Lin Jie (2014). Historical Changes and Contemporary Implications of the Essence of Higher Education Connotative Development, Journal of National Academy of Education Administration, (11): 3-8.

[39] Ministry of Education, Ministry of Finance, National Development and Reform Commission (2017). "Circular on Announcement of List of World-Class Universities and First-Class Disciplines for Universities and Construction of Disciplines" (Teaching Research Letter (2017) No. 2).

[40] Zhang Wei, Bian Cunxu (2018). The Value Logic and Practical Approach of "Double First-Class" Construction [J]. Modern Education Management, (01): 19-25.

[41] Tan Zhemin (2017). The Faculty is the Core of the "double first-Class" Construction, China Higher Education, (Z1): 26-28.

[42] Sun Yuqing (2016). Disciplines and Majors in Universities, China Higher Education, (07): 42-45.

[43] Jiang Hongxin (2016). Strengthening the orientation of education and promoting first-class education, China University Teaching,(11): 44-46.

[44] Li Hui(2014). The Construction of Textbooks under the Connotation of the Development of Higher Education: Based on the Thinking of American University Education and Teaching Reform, Higher Education Exploration,(06):128-131.

[45] Xi Jinping. Speech at the Symposium on Philosophy and Social Sciences, retrieved May 18, 2016, from http://news.xinhuanet.com/politics/2016-05/18/c_1118891128. htm.

[46] JIANG Ze-min (2008). Reflections on Energy Issues in China, Journal of Shanghai Jiaotong University,(03): 345-359.

[47] Liu Guoyu (2016). Pursuing Academic Excellence in Serving the State and Society: Thoughts on the Establishment of World-Class Disciplines in Universities in China, Academic Degrees \& Graduate Education,(08): 12-15.

[48] WU Zeng-li, GONG Hong-xin(2017). The Core Issues in the Research of "Double First Class" Construction, University Education Science, (04): 31-36.

[49] Jia Min (2016). Rationality Analysis of Industry Associations Participating in Modern Vocational Education Governance, China Higher Education Research, (02): 106-110.

[50] Yuan Guiren (2014). Deepening comprehensive reforms in the field of education Accelerating the modernization of educational governance systems and governance capabilities, China Higher Education, (05): 8-9. 